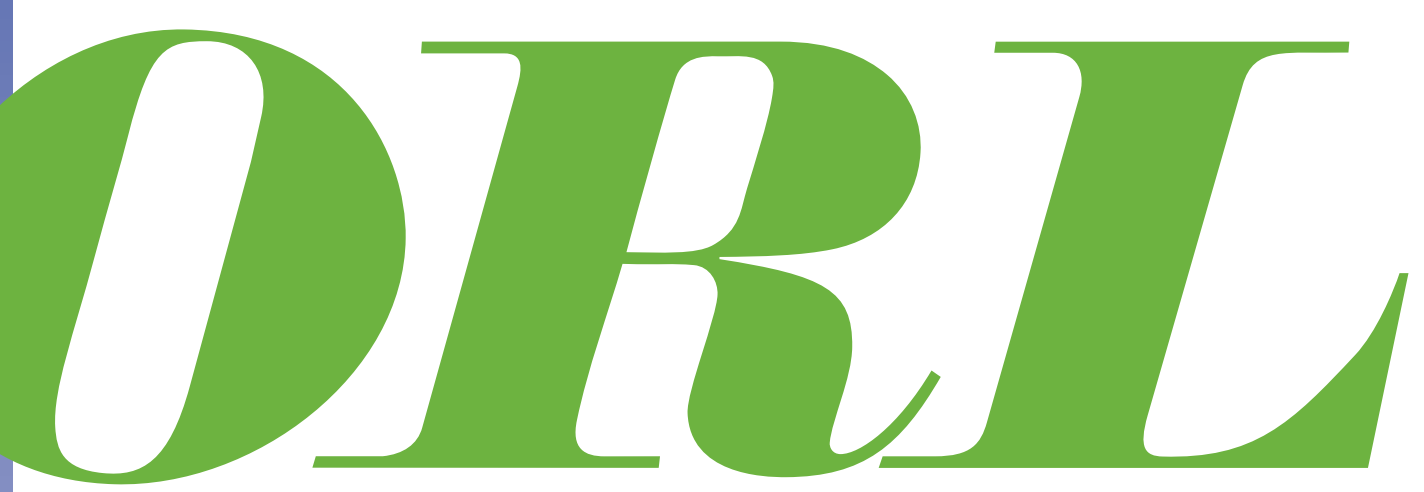

\title{
Journal for Oto-Rhino-Laryngology, Head and Neck Surgery
}
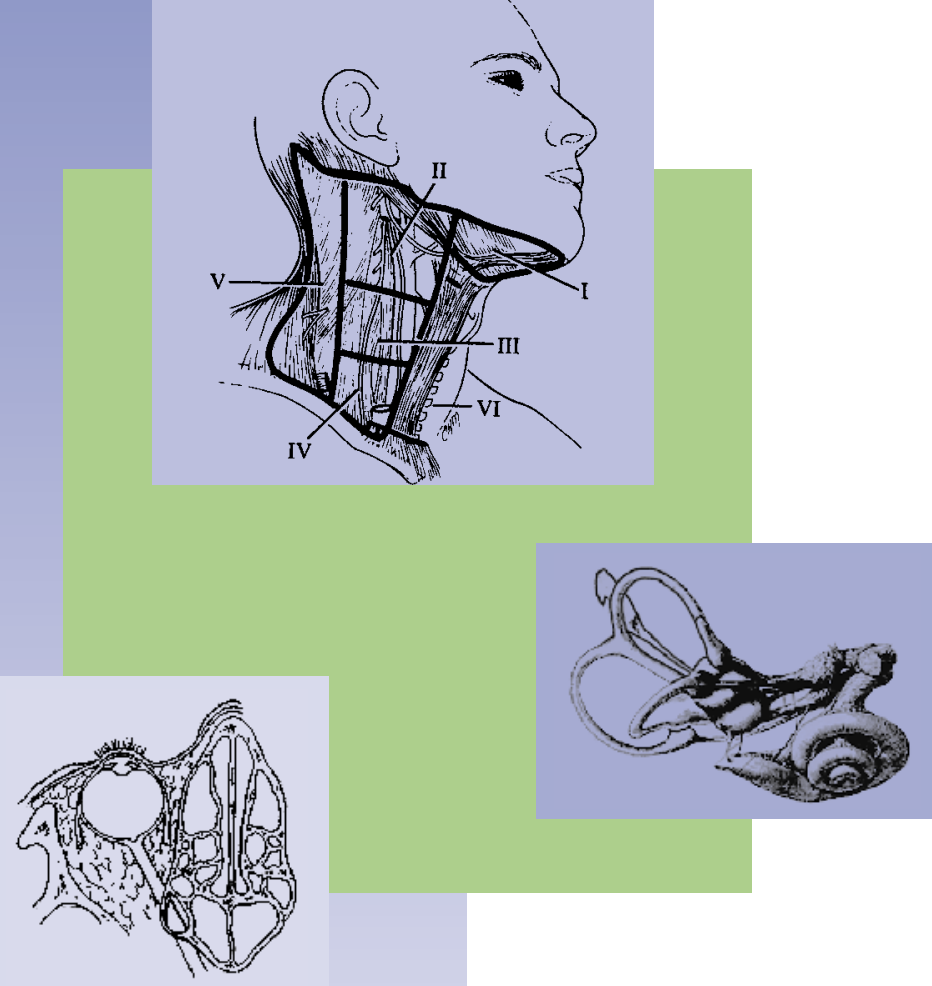


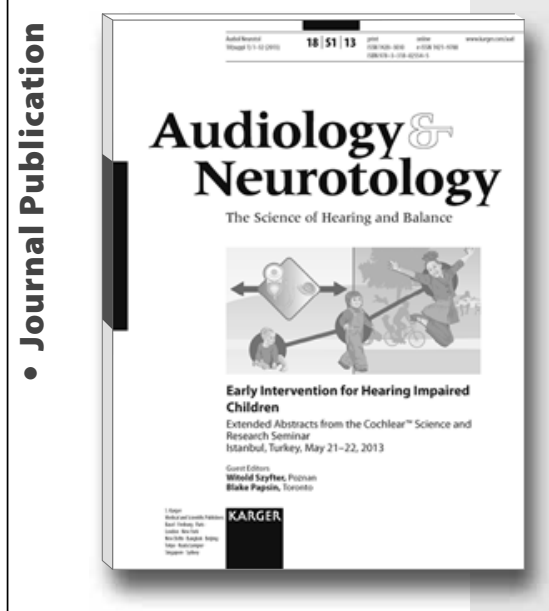

Early Intervention for Hearing Impaired Children

Cochlear ${ }^{\mathrm{TM}}$ Science and Research Seminar, Istanbul, May, 2013: Extended Abstracts

Editors: Szyfter, W. (Poznan);

Papsin, B.C. (Toronto, Ont.)

IV + 32 p., 10 fig., 3 tab., 2013

CHF 29.- / EUR 24.- / USD 34.00 (soft cover)

CHF 35- / EUR 29- / USD 41.00 (online)

Online version for institutional purchase

Prices subject to change

EUR price for Germany,

USD price for USA and Latin America only

ISBN 978-3-318-02554-5

e-ISBN 978-3-318-02555-2

Supplement Issue

Audiology and Neurotology

Vol. 18, Suppl. 1 (2013)

Included in subscription

Listed in MEDLINE/PubMed

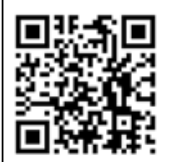

Dear Librarian

I have reviewed this publication and would like to recommend it for our library. Recommended by:

Department:

Date:

Signature:

Orders may be placed with any bookshop, subscription agency, directly with the publisher or through a Karger distributor.

\section{Early Intervention for Hearing Impaired Children}

Extended Abstracts from the Cochlear ${ }^{\mathrm{TM}}$

Science and Research Seminar

Istanbul, Turkey, May 21-22, 2013

\section{Editors \\ Witold Szyfter \\ Blake C. Papsin}

\section{Contents}

- Editorial: Szyfter, W.; Papsin, B.C.

- Polish Universal Neonatal Hearing Screening Program - 10 Years of Experience: Early Intervention - The Benefits and Why 'Early' Is Still Not a Standard Practice: Szyfter, W.; Wróbel, M.; Karlik, M.; Greczka, G.

- Neonatal Hearing Screening Program in the Tuscany Region: Berrettini, S.; Forli, F.; Lunardi, S.; Ghirri, P.

- Impact of Comprehensive Diagnostic Procedures: Newborn

Hearing Screening to Cochlear Implantation: Lesinski-Schiedat, A.; Illg, A.; Kanaan, N.; Lenarz, T.

- Disruptive Technology and the Importance of Bilateral Cochlear Implantation in Children: Papsin, B.C.; Cushing, S.L.; Gordon, K.A.

- Simultaneous Cochlear Implants Before 15 or 24 Months of Life? Burdo, S.; Moalli, R.

- Paediatric Cochlear Implantation Surgery: Surgical Aspects and Preliminary Results on Hearing Preservation, Electrode

Placement and Performance with the Cochlear ${ }^{\oplus} \mathrm{Cl} 422$ Implant:

Dietz, A.; Varonen, S.; Hyvärinen, A.; Löppönen, H.

- Cochlear Implantation in Young Post-Meningitis Patients:

Decision Making Based on Hearing Evaluation and Imaging: Merkus, P.; van Loon, M.C.; Hensen, E.F.

- Impact of Cochleovestibular Malformations in Treating Children with Hearing Loss: Sennaroglu, L.; Ozkan, H.B.; Aslan, F.

- How to Most Appropriately Fit a Paediatric Population: Müller-Deile, J.; Hey, M.

- Parental Involvement and Early Intervention: Their Role in Early Cochlear Implantation: Archbold, s.

Author Index 


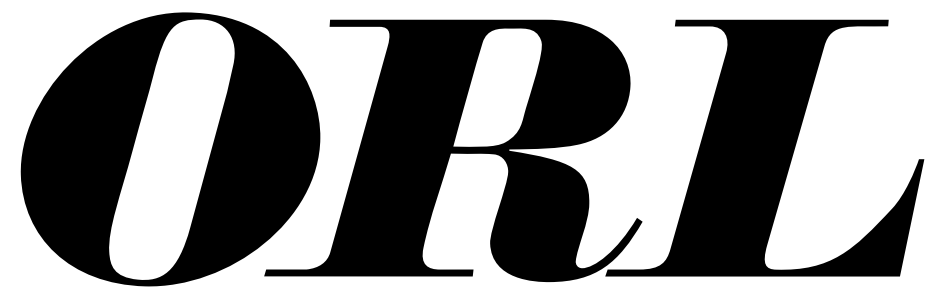

\section{Journal for Oto-Rhino-Laryngology, Head and Neck Sugery}

Founded 1938 as 'Practica Oto-Rhino-Laryngologica' by J. Berberich and E. Schlittler, continued by L. Rüedi 1947-1970, E. Huizinga 1948-1970, C.R. Pfaltz 1968-1984,

W. Arnold 1985-2002

Incorporating 'Oto-Rhino-Laryngologia Nova'

\section{Editor-in-Chief}

Bert W. O’Malley, Jr.,

Philadelphia, Pa. (USA)

Bert.OMalley@uphs.upenn.edu

\section{Co-Editor}

Daqing Li,

Philadelphia, Pa. (USA)

\section{Associate Editors}

Wolfgang Arnold, Kastanienbaum (Switzerland)

Fernando L. Dias, Rio de Janeiro (Brasil)

Hinrich Staecker, Kansas City, Kans. (USA)

Tatsuya Yamasoba, Tokyo (Japan)

\section{Controversial Issues Editor}

Jean-Philippe Guyot, Genève (Switzerland)

Basile N. Landis, Genève (Switzerland)

\section{International Editorial Board}

R.L. Alford, Houston, Tex.

M. Anniko, Uppsala

Y.A. Bayazit, Ankara

H.H. Birdsall, Houston, Tex.

P.J. Bradley, Nottingham

J. Califano, Baltimore, Md.

P.F. Castellanos, Bimingham, Ala.

C. Cernea, São Paulo

F.-L. Chi, Shanghai

A. Chiu, Tucson, Ariz.

N. Cohen, Philadelphia, Pa.

M.D. Eisen, Hartford, Conn.

L.M. Elden, Philadelphia, Pa.

E. Ferekidis, Athens

A. Ferlito, Udine

R.L. Ferris, Pittsburgh, Pa.

L.L. Gleich, Cincinnati, Ohio

D.-M. Han, Beijing

J.P. Harris, San Diego, Calif.

R. Häusler, Bern

I. Hochmair, Innsbruck

K. Hörmann, Mannheim

W. Hosemann, Greifswald
K.-B. Hüttenbrink, Köln

S. Iurato, Bari

A. Kakigi, Tokyo

B.N. Landis, Geneva

T. Linder, Luzern

S. Malekzadeh, Washington, D.C.

W.J. Mann, Mainz

G. Marioni, Padova

J.N. Palmer, Philadelphia, Pa.

R. Probst, Zürich

A. Rinaldo, Udine

R.J. Ruben, Bronx, N.Y.

I. Salahuddin, Karachi

A. Schrott-Fischer, Innsbruck

A. Shiotani, Saitama

T.N. Teknos, Columbus, Ohio

K. Tomoda, Osaka

R.P. Tufano, Baltimore, Md.

R.T. Younis, Miami, Fla.

P. Zbären, Bern 


\section{Submission}

Only original papers written in English should be submitted using the online submission website at:

\section{www.karger.com/orl}

Should you experience any problems with your submission, please contact the Editorial Office at:

\section{orl@karger.com}

Bert W. O’Malley, Jr. M.D.

S. Karger AG

Editorial Office ORL

PO Box

$\mathrm{CH}-4009$ Basel (Switzerland)

Tel. +4161306 1360

Fax +41613061434

Suggested reviewers: Please list four complete mailing and e-mail addresses of potential reviewers for your manuscript. The names you suggest should not be ORL Editorial Board members; should not have been co-authors or co-workers over the past 3 years nor should they be persons working in the same institution as yourself or any of the co-authors.

\section{Conditions}

All manuscripts are subject to editorial review. Manuscripts are received with the explicit understanding that they are not under simultaneous consideration by any other publication. Submission of an article for publication implies the transfer of the copyright from the author to the publisher upon acceptance. Accepted papers become the permanent property of $O R L$ and may not be reproduced by any means, in whole or in part, without the written consent of the publisher. It is the author's responsibility to obtain permission to reproduce illustrations, tables, etc. from other publications.

\section{Conflicts of Interest}

Authors are required to disclose any sponsorship or funding arrangements relating to their research and all authors should disclose any possible conflicts of interest. Conflict of interest statements will be published at the end of the article.

Types of Papers

Editorial

Review

Original Paper

High Impact Report

Case Report

How I do it

Letter to the Editor

\section{High Impact Reports}

Authors may also submit contributions to the new section 'Hight Impact Reports'. Papers should focus on novel and exciting translational and clinical research should comprise no more than four printed pages incl. 3 figures and 20 references and should be submitted explicitly for this section. An expedited publication time of 8 weeks after acceptance is intended.

Reviews are either invited, or may be submitted for consideration. Invited reviews, if accepted, are not subject to page charges. The recommended length is 6 printed pages (approx. 16 manuscript pages).

\section{Letter to the Editor}

Letters are only accepted if they directly concern articles previously published in this journal and clinical subjects related to the matters discussed. The editor reserves the right to submit copies of such letters to the authors of the articles concerned prior to publication in order to permit them to respond in the same issue of the journal. Letters should have a maximum of one printed page (350-420 words, up to 8 references).

\section{Case Report}

The publication space available for case reports is very limited. The journal only considers case reports with significant new insights, specific diagnostic methodology or with an extremely unusual and memorable course.

\section{Arrangement}

Title page: The first page of each paper should indicate the title, the authors' names, the institute where the work was conducted, and a short title for use as running head.

Full address: The exact postal address of the corresponding author complete with postal code must be given at the bottom of the title page. Please also supply phone and fax numbers, as well as e-mail address.

Key words: Please supply 3-10 key words in English that reflect the content of the paper.

Abstract: Each paper needs an abstract in English of not more than $\mathbf{2 0 0}$ words. The abstract is of utmost importance. It should contain the following information: purpose of the study, procedures, results, conclusions and message of the paper.

Footnotes: Avoid footnotes.

Tables and illustrations: Tables and illustrations (both numbered in Arabic numerals) should be stored in separate files. Tables require a heading and figures a legend, also in a separate file. When possible, group several illustrations in one block for reproduction (max. size $180 \times 223 \mathrm{~mm}$ ) or provide crop marks. B/w half-tone and color illustrations must have a final resolution of $300 \mathrm{dpi}$ after scaling, line drawings one of $800-1,200 \mathrm{dpi}$.

Color illustrations

Online edition: Color illustrations are reproduced free of charge. In the print version, the illustrations are reproduced in black and white. Please avoid referring to the colors in the text and figure legends.

Print edition: Up to 6 color illustrations per page can be integrated within the text at CHF 800.- per page.

References: In the text identify references by Arabic numerals [in square brackets]. Material submitted for publication but not yet accepted should be noted as [unpublished data] and not be included in the reference list. The list of references should include only those publications which are cited in the text. Do not alphabetize; number references in the order in which they are first mentioned in the text. The surnames of the authors followed by initials should be given. There should be no punctuation other than a comma to separate the authors. Preferably, please cite all authors. Abbreviate journal names according to the Index Medicus system. Also see International Committee of Medical Journal Editors: Uniform requirements for manuscripts submitted to biomedical journals (www.icmje.org).

Examples

(a) Papers published in periodicals: Chatel J-M, Bernard $\mathrm{H}$, Orson FM: Isolation and characterization of two complete Ara h 2 isoforms cDNA. Int Arch Allergy Immunol 2003;131:14-18.

(b) Papers published only with DOI numbers:

Theoharides TC, Boucher W, Spear K: Serum interleukin-6 reflects disease severity and osteoporosis in mastocytosis patients. Int Arch Allergy Immunol DOI: $10.1159 / 000063858$.

(c) Monographs: Matthews DE, Farewell VT: Using and Understanding Medical Statistics, ed 3, revised. Basel, Karger, 1996.

(d) Edited books: DuBois RN: Cyclooxygenase-2 and colorectal cancer; in Dannenberg AJ, Dubois RN (eds): COX-2. Prog Exp Tum Res. Basel, Karger, 2003, vol 37, pp 124-137.

Reference Management Software: Use of EndNote is recommended for easy management and formatting of citations and reference lists.

\section{Digital Object Identifier (DOI)}

S. Karger Publishers supports DOIs as unique identifier for articles. A DOI number will be printed on the title page of each article. DOIs can be useful in the future for identifying and citing articles published online without volume or issue information. More information can be found at www.doi.org.

\section{Author's Choice ${ }^{\mathrm{TM}}$}

Karger's Author's Choice ${ }^{\mathrm{TM}}$ service broadens the reach of your article and gives all users worldwide free and full access for reading, downloading and printing at www.karger.com. The option is available for a one-time fee of $\mathrm{CH}$ 3,000 .-, which is a permissible cost in grant allocation. More information can be found at www.karger.com/authors choice.

\section{Supplementary Material}

Supplementary material is restricted to additional data that are not necessary for the scientific integrity and conclusions of the paper. Please note that all supplementary files will undergo editorial review and should be submitted together with the original manuscript. The Editors reserve the right to limit the scope and length of the supplementary material. Supplementary material must meet production quality standards for Web publication without the need for any modification or editing. In general, supplementary files should not exceed $10 \mathrm{Mb}$ in size. All figures and tables should have titles and legends and all files should be supplied separately and named clearly. Acceptable files and formats are: Word or PDF files, Excel spreadsheets (only if the data cannot be converted properly to a PDF file), and video files (.mov, .avi, .mpeg).

\section{NIH-Funded Research}

The U.S. National Institutes of Health (NIH) mandates under the NIH Public Access Policy that final, peer-reviewed manuscripts appear in its digital database within 12 months of the official publication date. As a service to authors, Karger submits the final version of your article on your behalf to PubMed Central. For those selecting our premium Author's Choice ${ }^{\mathrm{TM}}$ service, we will send your article immediately upon publishing, accelerating the accessibility of your work without the usual embargo. More details on NIH's Public Access Policy is available at http://publicaccess.nih.gov/policy.htm

\section{Self-Archiving}

Karger permits authors to archive their pre-prints (i.e. prerefereeing) or post-prints (i.e. final draft post-refereeing) on their personal or institution's servers, provided the following conditions are met: Articles may not be used for commercial purposes, must be linked to the publisher's version, and must acknowledge the publisher's copyright. Authors selecting Karger's Author's Choice ${ }^{\mathrm{TM}}$ feature, however, are also permitted to archive the final, published version of their article, which includes copyediting and design improvements as well as citation links.

\section{Page Charges}

There are no page charges for papers of 4 or fewer printed pages (including tables, illustrations and references). Each additional complete or partial page is charged to the author at CHF 650.-. The allotted size of a paper is equal to approx. 10 manuscript pages (double-spaced, including tables, illustrations and references).

\section{Proofs}

Unless indicated otherwise, proofs are sent to the corresponding author and should be returned with the least possible delay. Alterations other than the correction of printer's errors are charged to the author.

\section{Reprints}

Order forms and a price list are sent with the proofs. Orders submitted after the issue is printed are subject to considerably higher prices

\section{KARGER}

E-Mail karger@karger.com www.karger.com
(C) 2013 S. Karger AG, Basel 
ISSN Print Edition: 0301-1569 ISSN Online Edition: 1423-0275

Journal Homepage: www.karger.com/orl

Publication Data: $O R L$ is published 6 times a year. Volume 75 with 6 issues appears in 2013.

Copyright: (c) 2013 S. Karger AG, Basel (Switzerland). All rights reserved. No part of this publication may be translated into other languages, reproduced or utilized in any form or by any means, electronic or mechanical, including photocopying, recording, microcopying, or by any information storage and retrieval system, without permission in writing from the publisher or, in the case of photocopying, direct payment of a specified fee to the Copyright Clearance Center.

Disclaimer: The statements, opinions and data contained in this publication are solely those of the individual authors and contributors and not of the publisher and the editor(s). The appearance of advertisements in the journal is not a warranty, endorsement, or approval of the products or services advertised or of their effectiveness, quality or safety. The publisher and the editor(s) disclaim responsibility for any injury to persons or property resulting from any ideas, methods, instructions or products referred to in the content or advertisements.
Subscription Rates: Subscriptions run for a full calendar year. Prices are given per year. Personal subscription:

Print or Online

CHF 795.-

EUR 641.-

USD 787.00

Print+Online combined CHF 843.-

EUR 680.-

USD 835.00

postage and handling (added to print and print+online)

CHF 43.20 Europe, CHF 62.40 Overseas

EUR 33.60

USD 57.60

Institutional subscription

Print or Online

Print+Online combined

CHF 1590.

EUR 1282.-

CHF 1749 .

USD 1732.00

postage and handling (added to print and print+online)

CHF 54.- Europe, CHF 78.- Overseas

EUR 42.-

USD 72.00

Airmail surcharge: CHF 52.50 / USD 49.50

Discount subscription prices:

Gesellschaft Schweizerischer HNO-Ärzte.
Back Volumes and Single Issues: Information on availability and prices of single print issues and print or electronic back volumes can be obtained from Customer Service atservice@karger.com.

Bibliographic Indices: This journal is regularly listed in bibliographic services, including Current Contents ${ }^{\circledR}$ and PubMed/MEDLINE.

Photocopying: This journal has been registered with the Copyright Clearance Center (CCC), as indicated by the code appearing on the first page of each article. For readers in the US, this code signals consent for copying of articles for personal or internal use, or for the personal or internal use of specific clients, provided that the stated fee is paid per copy directly to

Copyright Clearance Center Inc.

222 Rosewood Drive

Danvers, MA 01923 (USA)

A copy of the first page of the article must accompany payment. Consent does not extend to copying for general distribution, for promotion, for creating new works, or for resale. In these cases, specific written permission must be obtained from the copyright owner,

S. Karger AG, P.O. Box

CH-4009 Basel (Switzerland).

\begin{tabular}{|c|c|c|c|}
\hline $\begin{array}{l}\text { Subscription Orders: } \\
\text { Orders can be placed at agencies, } \\
\text { bookstores, directly with the Publisher } \\
\text { S. Karger AG } \\
\text { Medical and Scientific Publishers } \\
\text { Allschwilerstrasse } 10 \\
\text { CH-4009 Basel } \\
\text { Switzerland } \\
\text { t: }+41613061111 \\
\text { f: }+41613061234 \\
\text { e: karger@karger.com } \\
\text { w: www.karger.com } \\
\text { (for courier services only: } \\
\text { Allschwilerstrasse } 10 \\
\text { CH-4055 Basel) }\end{array}$ & $\begin{array}{l}\text { or further Karger offices } \\
\text { or representatives: } \\
\text { Germany } \\
\text { S. Karger GmbH } \\
\text { Postfach } \\
79095 \text { Freiburg } \\
\text { Deutschland } \\
\text { (Hausadresse: Wilhelmstrasse 20A, } \\
\text { 79098 Freiburg) } \\
\text { t: }+49761452070 \\
\text { f: +49 761 } 4520714 \\
\text { e: information@karger.de } \\
\text { w: www.karger.de } \\
\text { Japan } \\
\text { Karger Japan, Inc. } \\
\text { Shiba Daimon Asahi Bldg. 2F } \\
\text { 1-2-23 Shiba Daimon } \\
\text { Minato-ku } \\
\text { Tokyo 105-0012 } \\
\text { Japan } \\
\text { t: +81 } 364356242 \\
\text { f: +81 } 364356244 \\
\text { e: publisher@karger.jp } \\
\text { w: www.karger.jp }\end{array}$ & $\begin{array}{l}\text { USA } \\
\text { S. Karger Publishers, Inc. } \\
26 \text { West Avon Road } \\
\text { P.O. Box 529 } \\
\text { Unionville, CT } 06085 \\
\text { USA } \\
\text { Toll free: }+18008285479 \\
\text { t: }+18606757834 \\
\text { f: }+18606757302 \\
\text { e: karger@snet.net } \\
\text { France } \\
\text { Enter \& Read } \\
\text { Albertine Luginbuhl } \\
\text { 23, rue du Départ, boite } 37 \\
75014 \text { Paris } \\
\text { France } \\
\text { t: +33 (0) } 681047685 \\
\text { e: albertineluginbuhl@orange.fr } \\
\text { South East Asia, China and Taiwan } \\
\text { Karger Regional Office (Malaysia) } \\
\text { CEO Suite Kuala Lumpur } \\
\text { Quill 7, 27th Floor } \\
\text { Jalan Stesen Sentral } 5 \\
\text { KL Sentral } \\
\text { Kuala Lumpur } 50470 \\
\text { Malaysia } \\
\text { t: +60 3 2776 6803 } \\
\text { f: +60 3 2776 6999 } \\
\text { e: service@karger.cn }\end{array}$ & $\begin{array}{l}\text { Karger China } \\
\text { West/5F, China Life Tower } \\
\text { No.16, Chao Wai Street } \\
\text { Chaoyang District } \\
\text { Beijing } 100020 \\
\text { China } \\
\text { t: }+861058771408 \\
\text { f: }+861058771120 \\
\text { e: service@karger.cn; r.chew@karger.cn } \\
\text { w: www.karger.cn } \\
\text { India, Bangladesh, Sri Lanka } \\
\text { Karger India } \\
\text { Plot No. 17, Yusuf Sarai Market } \\
\text { B.L. Glass Building, 2nd Floor } \\
\text { Sri Aurobindo Marg } \\
\text { New Delhi } 110016 \\
\text { India } \\
\text { t: +91 } 1146029633 \\
\text { f: +91 } 1146029634 \\
\text { c: +91 } 9891052128 \\
\text { e: r.kumar@kargerindia.com } \\
\text { w: www.karger.com }\end{array}$ \\
\hline $\begin{array}{l}\text { Change of Address: } \\
\text { Both old and new address should be sent } \\
\text { to the subscription source. }\end{array}$ & & & \\
\hline
\end{tabular}

\section{KARGER}

E-Mail karger@karger.com www.karger.com
(C) 2013 S. Karger AG, Basel

The Journal Home Page is available at: www.karger.com/orl 


\section{Contents}

See the journal website for contents

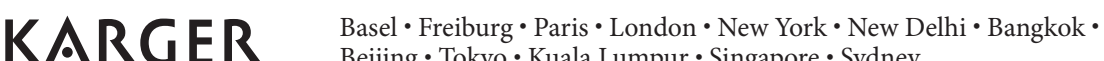
Beijing $\cdot$ Tokyo $\cdot$ Kuala Lumpur $\cdot$ Singapore $\cdot$ Sydney 


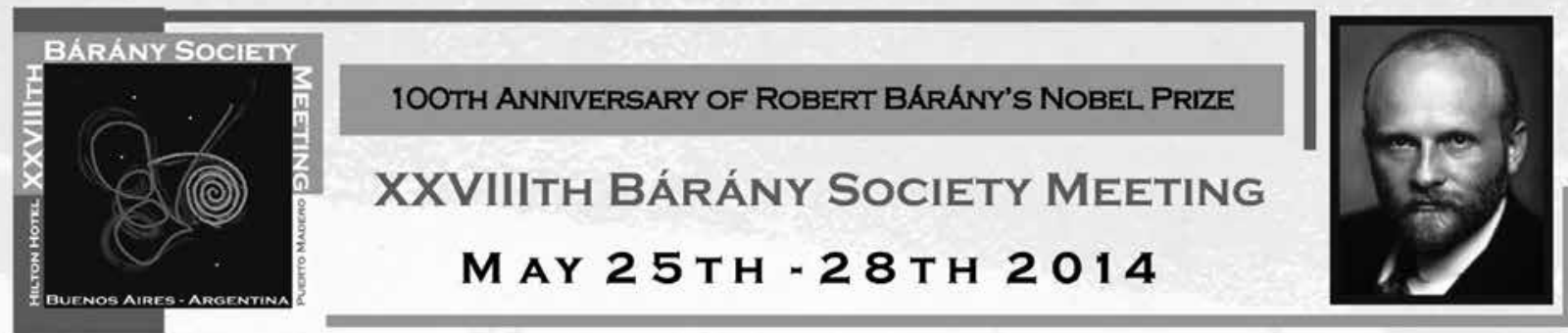

\section{World Congress on Vertigo and Balance Disorders}

Dear colleagues and members of the Bárány Society, having the opportunity to host our Society's meeting has been a long-awaited dream for the Latin American scientific community. This dream will come true in Buenos Aires, May 25-28, 2014.

Together with Prof. Adolfo Bronstein we are working on an attractive Scientific Programme that will include:

1) Lectures by invitation by outstanding scientist in the field of Neurotology,

2) plenary meeting of the International Classification Committee.,

3) plenty of time for the Vestibular Rehabilitation Seminar,

4) teaching courses, in this edition, apart from the traditional course in English, we will have a "Skill course" in Spanish, during the first day.

Also, given the fact that it will be the 100th anniversary of Robert Robert Barany's Nobel Prize, Prof. Göran Laurell will deliver a welcoming speech about him and about the history of chair of Uppsala.

But, most important, a Meeting is the excuse to stop, reunite and plan, a break in our journey to renew our friendship and scientific collaboration of so many years.

Let the words of Robert Bárány "The incorrectness and weaknesses of a theory cause other minds to formulate the problems more exactly and in this way scientific progress is made" be the motto of this meeting.

Buenos Aires is waiting for you, to offer its music, its fantastic architecture and culture, as well as the rest of Argentina, with its great landscapes and its beautiful and warm people.

Buenos Aires is waiting for you, to offer its music...

Prices in USD

Registration Fees

\begin{tabular}{|l||lr||lr||}
\hline & \multicolumn{2}{|c|}{$\begin{array}{c}\text { From Nov 26, 2013 } \\
\text { to May 25, 2014 }\end{array}$} & \multicolumn{2}{|c|}{ On site } \\
\hline Members & USD & 800.00 & USD & 850.00 \\
\hline No Members & USD & 900.00 & USD & 950.00 \\
\hline Non Physicians & USD & 700.00 & USD & 750.00 \\
\hline \hline
\end{tabular}

web: www.barany2014.com.ar

mail: barany2014@congrex.com.pa

Sponsored by:

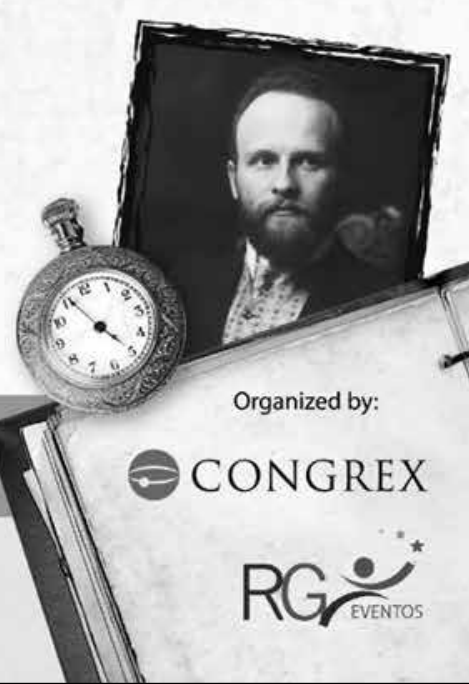




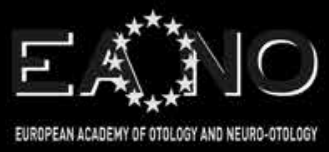

$7^{\text {th }}$ Instructional Workshop of European Academy of Otology and Neuro-Otology

\section{SEPTEMBER 13-16, 2014 - SIENA, ITALY}

FrANCO IRABAIZIINI, Concress Chairman/GREGORIO BABIGHIAN, Honorary President

mixed with

Consensus in Auditory Implants

European Guidelines in Otology and Neuro-Otology

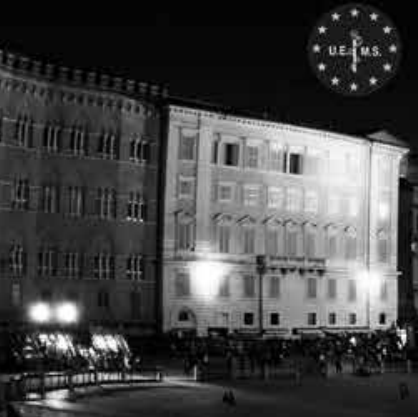

\section{A Arificilar Event Approach.}

\section{European \\ Congresson Head \& Neck}

$24^{402} 6^{\text {th }}$ April 2014 Oncology

ACC - Arena and Convention Centre Liverpool UK
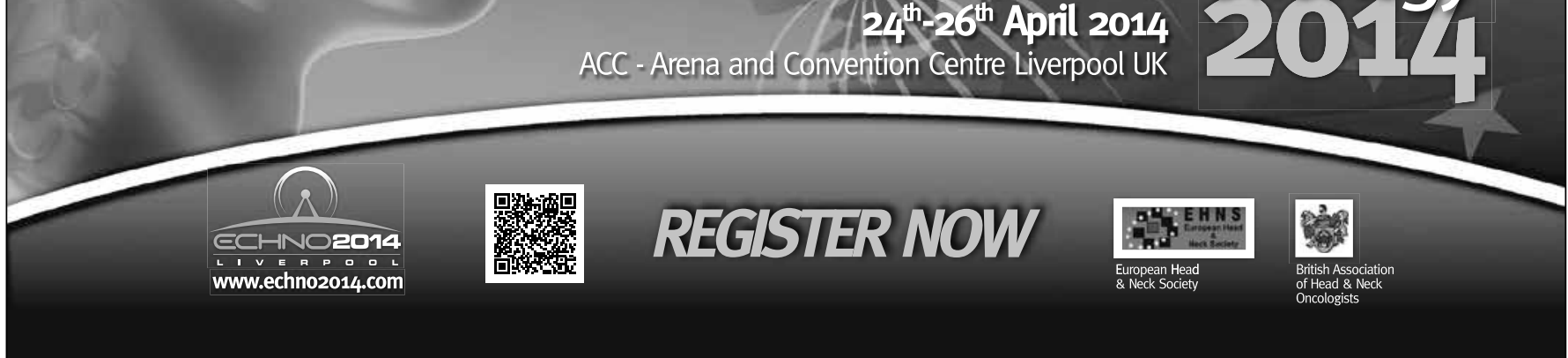


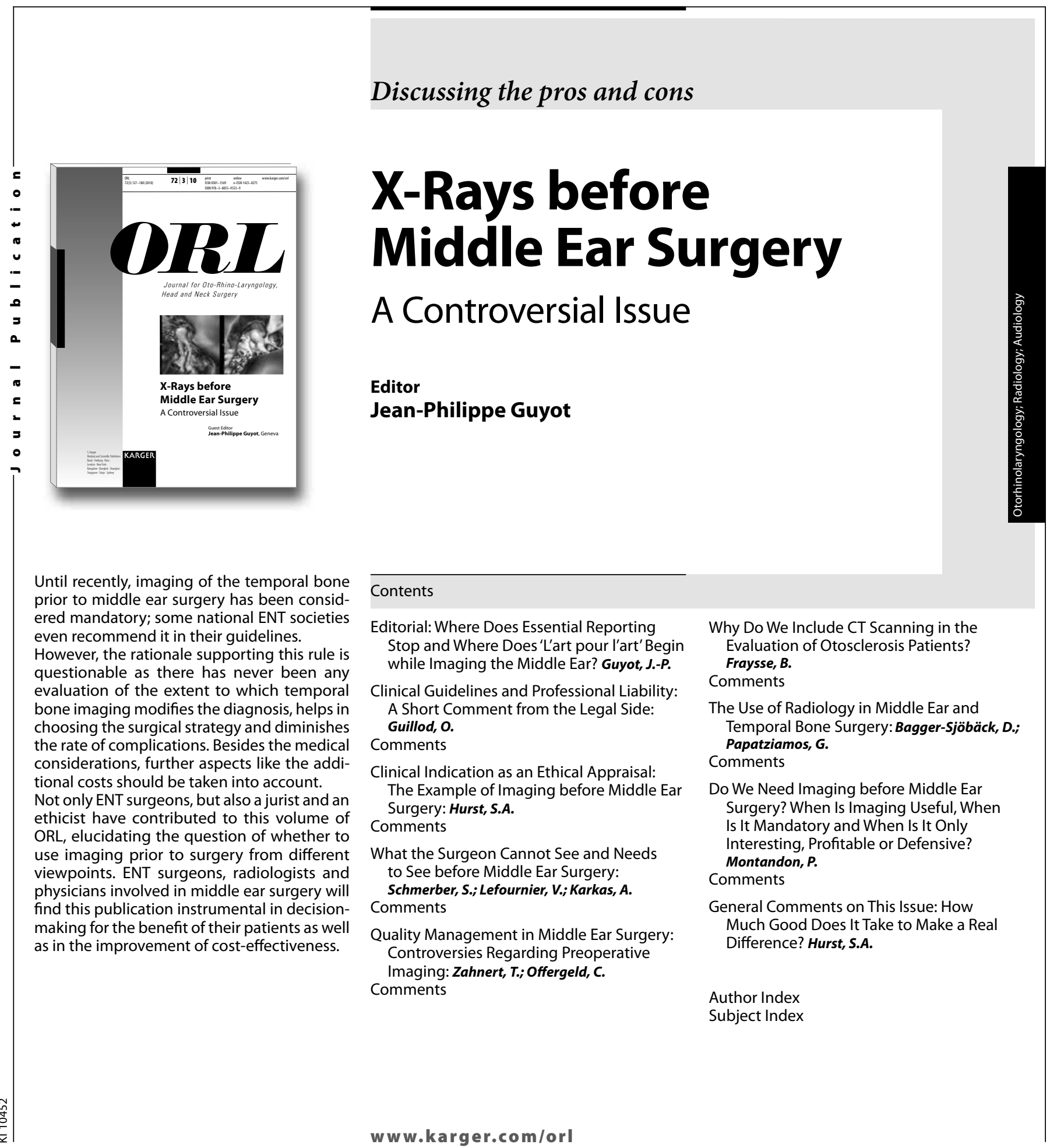

ORL

Editor: O'Malley, B.W. Jr. (Philadelphia, Pa.)

ISSN 0301-1569 / e-ISSN 1423-0275

Special issue: Vol. 72, Vol. 3 (2010)

Included in subscription

X-Rays before Middle Ear Surgery

A Controversial Issue

Editor: Guyot, J.P. (Geneva)

54 p., 28 fig., 2 tab., soft cover, 2010

54 p., 28 fig., 2 tab., soft cover, 2010
CHF 29.- / EUR 24.- / USD 34.00

Prices subject to change

EUR price for Germany, USD price for USA only

ISBN 978-3-8055-9533-9

e-ISBN 978-3-8055-9534-9

KARGER

\section{Please send: __ copy/ies}

Postage and handling free with prepayment

$\varepsilon$

Payment:

Please charge to my credit card

- $\square$ American Express $\square$ Diners $\square$ Eurocard

ᄂ $\square$ MasterCard $\square$ Visa

- Card No

๑

ర Exp. date

-

- $\mathrm{CVV} / \mathrm{CVC}$

( 3 digits in the signature field on the back of Visa and MasterCard)

$\square$ Check enclosed $\square$ Please bill me

Orders may be placed with any bookshop, subscription agency, directly with the publisher or through a Karger distributor.
Fax: +41613061234

S. Karger AG, P.O. Box, CH-4009 Basel (Switzerland) E-Mail orders@karger.ch, www.karger.com

Name/Address: 


\section{INTERNATIONAL TINNITUS SEMINAR}

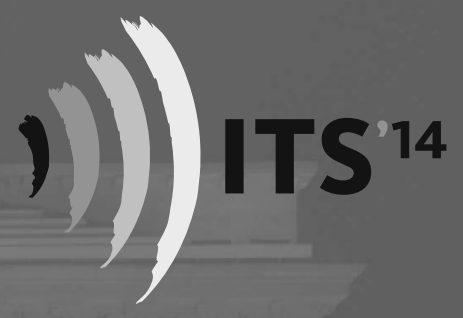

\section{1 - 24 MAY 2014 · BERLIN, GERMANY LANGENBECK-VIRCHOW-HAUS}

www.international-tinnitus-seminar-2014.com
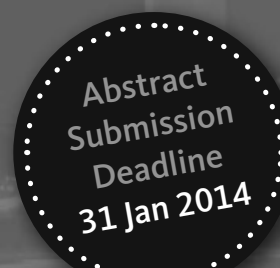

CONGRESS AND EXHIBITION OFFICE

CPO HANSER SERVICE GmbH

Paulsborner Str. 44, 14193 Berlin, Germany

Phone: $+49-(0) 30-3006690$

Email: its2014@cpo-hanser.de

F14384

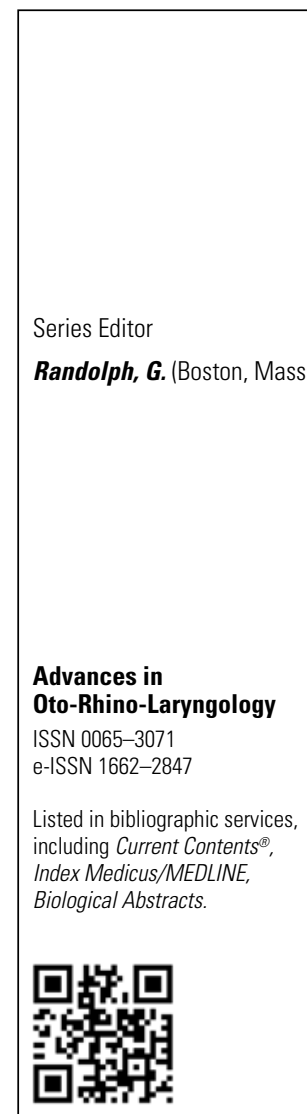

Read it online: www.karger.com/adorl

\section{Advances in Oto-Rhino-Laryngology}

Presents complete coverage from basic research to clinical studies

Material for each volume in this series has been skillfully selected to document the most active areas of otorhinolaryngology and related specialties, such as neuro-otology and oncology. The series reproduces results from basic research and clinical studies pertaining to the pathophysiology, diagnosis, clinical symptoms, course, prognosis and therapy of a variety of ear, nose and throat disorders. The numerous papers correlating basic research findings and clinical applications are of immense value to all specialists engaged in the ongoing efforts to improve management of these disorders. Acting as a voice for its field, the series has also been instrumental in developing subspecialties into established specialties.

\section{Vol. 74: Comprehensive \\ Techniques in CSF Leak Repair and Skull Base Reconstruction \\ Editor: Bleier, B.S. (Boston, Mass.) \\ $X+190$ p., 74 fig., 49 in color, 12 tab., hard cover + online supplementary material, 2013 \\ CHF 229. - / EUR 191. - / USD 269.00 ISBN 978-3-8055-9952-8}

Vol. 73: Pediatric Airway Surgery

Editors: Hartnick, C.J.; Hansen, M.C. (Boston, Mass.); Gallagher, T.O.

(Portsmouth, Va.)

VIII + 158 p., 130 fig., 89 in color,

1 tab., hard cover + online supplement material, 2012

CHF 198. - / EUR 165.- / USD 233.00 ISBN 978-3-8055-9931-3

'All in all, an excellent read for the paediatric otolaryngologist. ENT \& Audiology News

\section{Vol. 72: Recent Advances in} Tonsils and Mucosal Barriers of the Upper Airways

7th International Symposium on

Tonsils and Mucosal Barriers of the Upper Airways, Asahikawa, July 2010 Proceedings

Editors: Harabuchi, Y.: Hayashi, T.

Katada, A. (Asahikawa)

XII + 234 p., 43 fig., 18 in color, 17 tab., hard cover, 2011

CHF 184.- / EUR 153.- / USD 216.00 ISBN 978-3-8055-9722-7

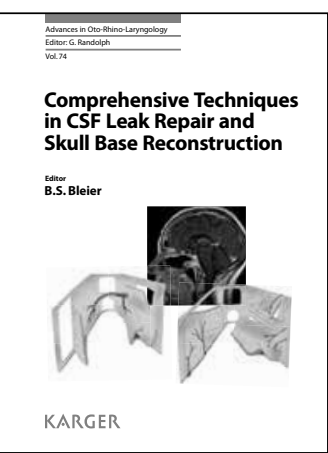

Vol. 71: Implantable Bone Conduction Hearing Aids Editors: Kompis, M :

Caversaccio, M.-D. (Bern)

VIII + 156 p., 74 fig., 42 in color, 18 tab, hard cover, 2011

CHF 228 - / EUR 190 - / USD 268.00 ISBN 978-3-8055-9699-2

'This volume is a pleasure to read and is a must for both the novice and for the expert who wants to renew his her knowledge on the subject.' ENT \& Audiology News 


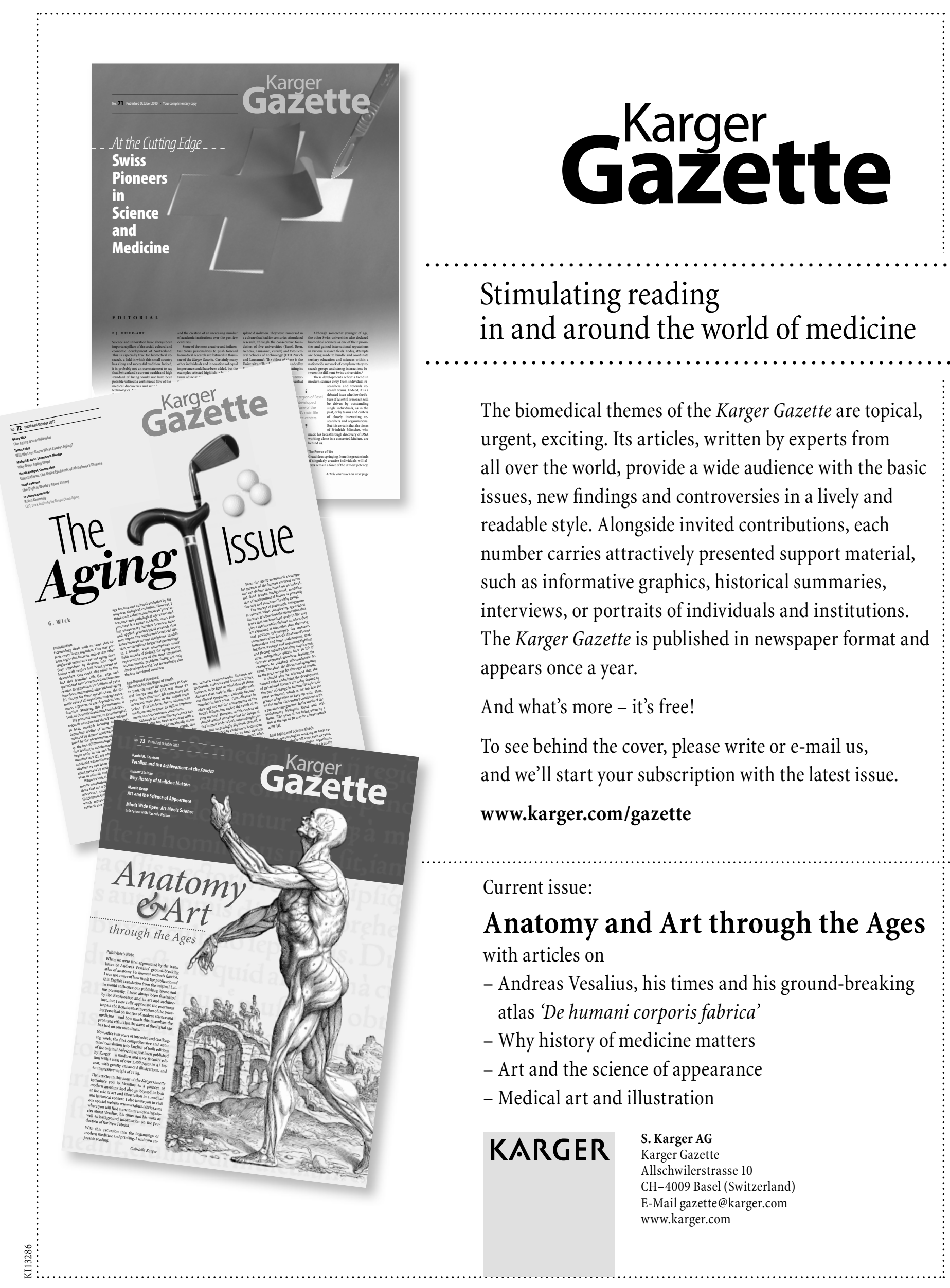




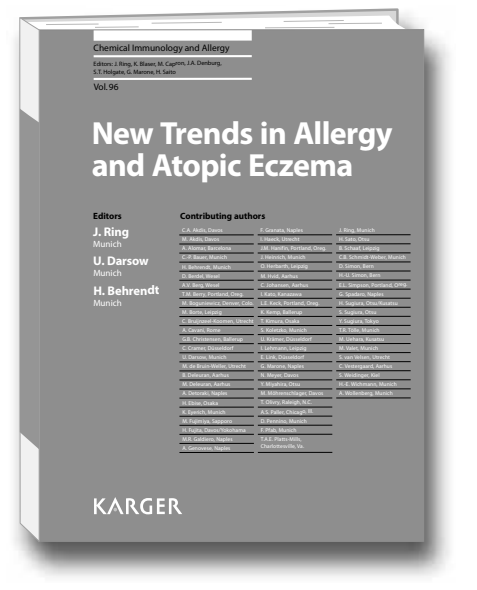

\title{
New Trends in Allergy and Atopic Eczema
}

\author{
Editors \\ Johannes Ring \\ Ulf Darsow \\ Heidrun Behrendt
}

\section{Contents}

\section{Preface}

Ring, J.; Darsow, U.; Behrendt, H.

\section{Allergy and Environment:}

Determinants of Allergy Development

Allergy in Evolution: Platts-Mills, T.A.E.

Climate Change, Environment and Allergy:

Behrendt, H.; Ring, J.

The Hygiene Hypothesis Does Not Apply to Atopic Eczema in Childhood: Cramer, C.; Link, E.; Koletzko, S.; Lehmann, I.; Heinrich, J.; Wichmann, H.-E.; Bauer, C.-P.; v. Berg, A.; Berdel, D.; Herbarth, O.; Schaaf, B.; Borte, M.; Behrendt, H.; Krämer, U.

Molecular Genetics of Atopic Eczema: Ring, J.; Möhrenschlager, M.; Weidinger, $S$.

\section{Pathogenesis of the Deviated Immune} Response

Mechanisms of Immune Tolerance to Allergens: Fujita, H.; Meyer, N.; Akdis, M.; Akdis, C.A.

Th17 and Th22 in Skin Allergy: Cavani, A.; Pennino, D.; Eyerich, $K$.

IL-25 Induces Both Inflammation and Skin Barrier Dysfunction in Atopic Dermatitis: Deleuran, M.; Hvid, M.; Kemp, K.; Christensen, G.B.; Deleuran, B.; Vestergaard, C.

Angiogenesis, Lymphangiogenesis and Atopic Dermatitis: Genovese, $A_{\text {.; }}$ Detoraki, A.; Granata, F.; Galdiero, M.R.; Spadaro, G.; Marone, $G$.

What Can Dogs Bring to Atopic Dermatitis Research? Olivry, $\boldsymbol{T}$.

Can Microbial Superantigens Influence Atopic Dermatitis Flares? Alomar, $\boldsymbol{A}$.

Inflammation-Induced Alterations in the Skin Barrier Function: Implications in Atopic Dermatitis: Vestergaard, C.; Hvid, M; Johansen, C.; Kemp, K.; Deleuran, B.; Deleuran, $M$.

\section{Clinical Aspects}

Itch and Eczema: Darsow, U.; Pfab, F.; Valet, $\boldsymbol{M . ;}$ Tölle, T.R.; Ring, J.

Eczema Herpeticum: Wollenberg, $\boldsymbol{A}$.

Bone Mineral Density in Patients with Atopic Dermatitis: Haeck, l.; van Velsen, S.; de Bruin-Weller, M.; Bruijnzeel-Koomen, C.
Immunosuppressive Effect of ProlactinInduced Protein: Sugiura, S.; Fujimiya, $\boldsymbol{M}_{\text {.; }}$ Ebise, H.; Miyahira, Y.; Kato, I.; Sugiura, Y.; Kimura, T.; Uehara, M.; Sato, H.; Sugiura, $H$.

\section{Therapy and Management}

Is Food Allergy Testing Reliable in Pediatric Atopic Dermatitis? A Population-Based Study: Keck, L.E.; Simpson, E.L.; Berry, T.M.; Hanifin, J.M.

New Strategies for Dealing with Staphylococcus aureus Colonization and the Emerging Methicillin-Resistant Staphylococcus aureus Epidemic in Atopic Dermatitis: Boguniewicz, $\boldsymbol{M}$.

Anti-IL-4 as a New Strategy in Allergy: Schmidt-Weber, C.B.

New Drug Targets in Atopic Dermatitis: Simon, D.; Simon, H. $U$.

Latest Approaches to Treating Atopic Dermatitis: Paller, A.S.

Author Index

Subject Index

\section{KARGER}

Chemical Immunology and Allergy, Vol. 96 Series Editors: Ring, J. (Munich); Blaser, K. (Davos); Capron, M. (Lille); Denburg, J.A. (Hamilton); Holgate, S.T (Southampton); Marone, G. (Napoli); Saito, H. (Tokyo) ISSN 1660-2242 / e-ISSN 1662-2898

New Trends in Allergy and Atopic Eczema Editors: Ring, J.; Darsow, U.; Behrendt, H. (Munich) XII + 146 p., 24 fig., 8 in color, 6 tab., hard cover, 2012 CHF 164.- / EUR 137.- / USD 193.00

Prices subject to change

Prices subject to change
EUR price for Germany, USD price for USA only ISBN 978-3-8055-9894-1 e-ISBN 978-3-8055-9895-8
Please send:

\section{copy/ies}

Postage and handling free with prepayment

E - Payment:

Please charge to my credit card

- $\square$ American Express $\square$ Diners

ᄂ $\square$ MasterCard $\square$ Visa

- Card No.

-

ర Exp. date

- CVV/CVC

( 3 digits in the signature field on the back of Visa and MasterCard)

$\square$ Check enclosed $\quad \square$ Please bill me

Orders may be placed with any bookshop, subscription agency, directly with the publisher or through a Karger distributor.
Fax: +41 613061234

S. Karger AG, P.O. Box, CH-4009 Basel (Switzerland) E-Mail orders@karger.ch, www.karger.com

Name/Address: 


\section{The independent journal of current basic science and clinical research}

\section{Audiology Neurotology \\ The Science of Hearing and Balance}

Editor-in-Chief

\section{J.P. Harris, San Diego, Calif.}

Associate Editors
P. Avan, Clermont-Ferrand
J.P. Carey, Baltimore, Md.
M. Hultcrantz, Stockholm
J. Nadol, Boston, Md.
A.F. Ryan, La Jolla, Calif.
J. Schacht, Ann Arbor, Mich.
C. Schreiner,
San Francisco, Calif.

Impact Factor: 2.318

\section{Audiology Neurotology}

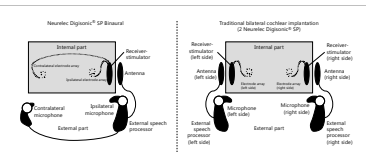

More information at

\section{www.karger.com/aud}

- Pay-per-View and Subscriber Access to Full Text

- Full Table of Contents

- Full Editorial Board

- Free Abstracts and Selected Articles

- Online Sample Issue

- Submission/Guidelines for Authors

- Subscription Details

- Free Alert Service

- Online Library Recommendation

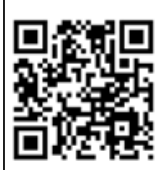

Audiology \& Neurotology

2014: Volume 19

6 issues per volume

Language: English

ISSN 1420-3030 (print)

ISSN 1421-9700 (online)

Listed in bibliographic services, including Current Contents $\%$ /Life Sciences, Pubmed/MEDLINE, Excerpta Medica, Biological Abstracts

\section{Selected contributions}

- Factors Affecting Auditory Performance of Postlinguistically Deaf Adults Using Cochlear Implants: An Update with 2251 Patients: Blamey, P. (Melbourne, Vic.); Artieres, F. (Palavas-les-Flots/Montpellier); Başkent, D. (Groningen); Bergeron, F. (Québec, Qué.) Beynon, A. (Nijmegen); Burke, E. (London); Dillier, N. (Zurich); Dowell, R. (Melbourne, Vic.); Fraysse, B. (Toulouse); Gallégo, S. (Lyon); Govaerts, P.J. (Antwerp); Green, K. (Manchester); Huber, A.M. (Zurich); Kleine-Punte, A. (Antwerp); Maat, B. (Groningen); Marx, M. (Toulouse); Mawman, D. (Manchester); Mosnier, I. (Clichy); 0'Connor, A.F. (London); $0^{\prime}$ Leary, S. Rousset, A. (Melbourne, Vic.); Schauwers, K. (Antwerp); Skarzynski, H. (Warsaw); Skarzynski, P.H. (Warsaw/Kajetany); Sterkers, O. (Clichy); Terranti, A. (Lille); Truy, E. (Lyon); Van de Heyning, P. (Antwerp); Venail, F. (Montpellier); Vincent, C. (Lille); Lazard, D.S. (Melbourne, Vic.)

- Does 'Cochlear Ménière's Disease' Exist? An Electrocochleographic and Audiometric Study: Claes, G.M.E.; De Valck, C.F.J.; Van de Heyning, P.; Wuyts, F.L. (Antwerp)

- What Is the Site of Origin of Cochleovestibular Schwannomas?: Roosli, C. (Boston, Mass./Zurich); Linthicum, F.H., Jr. (Los Angeles, Calif.); Cureoglu, S. (Minneapolis, Minn.); Merchant, S.N. (Boston, Mass.)

- Conditions for Highly Efficient and Reproducible Round-Window Stimulation in Humans: Schraven, S.P.; Hirt, B.; Goll, E.; Heyd, A.; Gummer, A.W.; Zenner, H.-P.; Dalhoff, E. (Tübingen)

- Tinnitus before and 6 Months after Cochlear Implantation: Kompis, M. (Bern); Pelizzone, M. (Geneva); Dillier, N. (Zurich); Allum, J. (Basel); DeMin, N. (Lucerne); Senn, P. (Bern)

- Psychoacoustic Performance and Music and Speech Perception in Prelingually Deafened Children with Cochlear Implants: Jung, K.H. (Seattle, Wash./Busan); Won, J.H.; Drennan, W.R.; Jameyson, E.; Miyasaki, G.; Norton, S.J.; Rubinstein, J.T. (Seattle, Wash.) - Canalith Repositioning Procedures among 965 Patients with Benign Paroxysmal Positional Vertigo: Prokopakis, E.; Vlastos, I.M.; Tsagournisakis, M.; Christodoulou, P. (Heraklion); Kawauchi, H. (Izumo); Velegrakis, G. (Heraklion)
Audiology and Neurotology provides a forum for the publication of the most-advanced and rigorous scientific research related to the basic science and clinical aspects of the auditory and vestibular system and diseases of the ear. This journal seeks submission of cutting edge research opening up new and innovative fields of study that may improve our understanding and treatment of patients with disorders of the auditory and vestibular systems, their central connections and their perception in the central nervous system. In addition to original papers the journal also offers invited review articles on current topics written by leading experts in the field.

The journal is of primary importance for all scientists and practitioners interested in audiology, otology and neurotology, auditory neurosciences and related disciplines. 


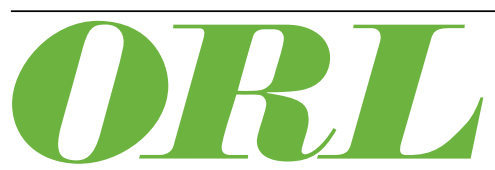

Original Papers

314 Comparison of the Effects of Desflurane and Sevoflurane on Middle Ear Pressure: A Randomized Controlled Clinical Trial

Duger, C.; Dogan, M.; Isbir, A.C.; Ozdemir Kol, I.; Gursoy, S.; Kaygusuz, K.; Sahin, O.F.;

Uysal, I.O.; Mimaroglu, C. (Sivas)

320 Epidemiologic Factors and Surgical Outcomes in Patients with Nasal Polyposis and Asthma

Bush, C.M.; Jang, D.W.; Champagne, J.P.; Kountakis, S.E. (Augusta, Ga.)

332 Expression of CXCR4 Is Associated with Progression and Invasion in Patients with Nasal-Surface Basal Cell Carcinoma

Xu, C.-Z.; Wang, P.-H.; Yan, X.-J.; Wang, T.; Chen, D.; Zhang, Z.-J.; Shi, R.-J. (Shanghai)

342 Glucose Metabolism in the Primary Auditory Cortex of Postlingually Deaf Patients: An FDG-PET Study

Okuda, T.; Nagamachi, S.; Ushisako, Y.; Tono, T. (Miyazaki)

350 Thyroidectomy for Graves' Disease: A Feasibility Study of the Robotic Transaxillary Approach

Noureldine, S.I.; Yao, L.; Wavekar, R.R.; Mohamed, S.; Kandil, E. (New Orleans, La.)

357 Evaluation of Vestibular Function in Patients with Chronic Suppurative Otitis Media Mostafa, B.E.; Shafik, A.G.; El Makhzangy, A.M.N.; Taha, H.; Mageed, H.M.A. (Cairo)

361 Balloon Dilatation of the Eustachian Tube: Postoperative Validation of Patient Satisfaction

Bast, F. (London); Frank, A.; Schrom, T. (Bad Saarow)

Case Report

309 Hyalinizing Trabecular Tumor Masquerading as Papillary Thyroid Carcinoma on Fine-Needle Aspiration

Howard, B.E.; Gnagi, S.H.; Ocal, I.T.; Hinni, M.L. (Phoenix, Ariz.)

How I Do It

325 A New Temporal Bone and Cadaver Head Holder for Temporal Bone Surgical Technique Training

Feng, G.; Lv, W.; Tian, X.; Wu, H.; Gao, Z. (Beijing)

366 Acknowledgement to Reviewers

after 367 Contents, Vol. 75, 2013

\section{KARGER}

